\title{
Anestesi untuk Seksio Sesarea pada Pasien dengan Hipertensi Intrakranial Idiopatik
}

\author{
Dewi Yulianti Bisri \\ Departemen Anestesiologi \& Terapi Intensif Fakultas Kedokteran Universitas Padjadjaran-RSUP Dr. Hasan \\ Sadikin Bandung
}

\begin{abstract}
Abstrak
Hipertensi intrakranial idiopatik (Idiophatic intracranial hypertension/IIH) atau benign intracranial hypertension atau pseudotumor cerebri adalah kasus jarang dengan penyebab yang tidak diketahui, dan paling sering terlihat pada wanita obes dalam masa reproduktif(19,3/100.000), dan kadang-kadang terjadi pada wanita hamil. Hipertensi intrakranial idiopatik adalah suatu sindroma yang khas ditandai adanya peningkatan tekanan intrakranial tanpa hidrocefalus atau lesi massa dengan peningkatan tekanan cairan cerebrospinal dan komposisi cairan serebrospinal yang normal. Kehamilan dan estrogen eksogen dapat memicu IIH atau memperburuknya dan dapat terjadi pada setiap semester kehamilan, dan outcome visual sama seperti wanita tidak hamil dengan IIH. Tidak ada peningkatan angka keguguran. Abortus terapeutikus untuk membatasi perkembangan IIH tidak merupakan indikasi, dan kehamilan selanjutnya tidak meningkatkan risiko kekambuhan. Gambaran klinis sakit kepala dan kehilangan penglihatan dengan adanya papil edema. Tujuan terapi adalah melindungi penglihatan dan memperbaiki keluhan. Terapi medikal umumnya analgesik, kortikosteroid, carbonic anhydrase inhibitors, dan diuretik. Bila pengendalian adekuat tidak tercapai maka indikasi dilakukan punksi lumbal untuk mengeluarkan cairan serebrospinal, pengakhiran kehamilan melalai rute yang paling cepat, apakah dilakukan melalui induksi persalinan atau seksio sesarea. Prognosis IIH pada kehamilan baik untuk ibu dan bayi. Anestesi dapat dilakukan dengan spinal anestesia, epidural anestesia, combined spinal epidural atau anestesi umum.
\end{abstract}

Kata kunci: anestesi, hipertensi intrakranial idiopatik, seksio sesarea, kehilangan penglihatan

JNI 2018;7(3): 198-206

\section{Anesthesia for Cesarean Section in Patient with Idiopathic Intracranial Hypertension}

\begin{abstract}
Idiopathic intracranial hypertension (IIH) or benign intracranial hypertension or pseudotumor cerebri is a rare disorder of unknown etiology that is most often seen in obese women of reproductive age $(19.3 / 100,000)$ and is reported only occasionally during pregnancy. It is a syndrome characterized by increased intracranial pressure without hydrocephalus or mass lession with elevated cerebrospinal fluid (CSF) pressure and normal CSF composition. Both pregnancy and exogenous estrogens are though to promote IIH or worsen it. It can occur in any trisemester during pregnancy, and the visual outcome is the same as for non pregnant patient with IIH. There is no increase in fetal wastage. Therapeutic abortion to limit its progression is not indicated, and subsequent pregnancies do not increase the risk of reccurence. Clinically present headache and loss of visions objectifying papil edema. The aim of treatment is to preserve vision and improve symptoms. The usual medical treatment is based on analgesics, corticosteriod, carbonic anhydrase inhibitors, and diuretics. If adequate control is not achieved lumbar puncture is indicated for extracting CSF. Uncontrolled intracranial hypertension is requiring terminated of the pregnancy as soon as posibble, either through induction or caesaeran section. The prognosis for IIH in pregnancy is excelent for both mother and baby. Anesthesia can be done with spinal anestheia, epidural anesthesia, combined spinal epidural or general anesthesia.
\end{abstract}

Key words: Anesthesia, caesarean section, idiophatic intracranial hypertension, visual loss 


\section{Pendahuluan}

Hipertensi intrakranial idiopatik (Idiopathic intracranial hypertension/IIH) adalah suatu penyakit yang belum diketahui penyebabnya dan dihubungkan dengan peningkatan tekanan intrakranial. Secara predominan mengenai wanita usia subur (childbearing age) dengan obesitas, didapatkan peningkatan tekanan intrakranial tanpa hidrosefalus atau lesi massa dengan komposisi cairan serebrospinal yang normal. Keluhan yang paling umum adalah sakit kepala sebagai akibat dari peningkatan tekanan intrakranial. ${ }^{1}$

Keluhan dan gejala dari hipertensi intrakranial adalah pasien tetap sadar, akan tetapi, tidak ada penemuan neurologik yang terlokalisir. Tidak ada bukti deformitas atau obstruksi sistem ventrikular dan pemeriksaan neurodiagnostik semuanya normal kecuali peningkatan tekanan cairan serebrospinal $\left(>200 \mathrm{mmH}_{2} \mathrm{O}\right.$ pada pasien non obes dan $>250 \mathrm{mmH}_{2} \mathrm{O}$ pada pasien obes). Gejala neuroimaging dari peningkatan tekanan intrakranial berupa empty sella syndrome, sinus lateralis kolaps, fallened globes. Tidak ditemukan penyebab sekunder dari hipertensi intrakranial. Definisi ini diambil dari kriteria modifikasi Dandy untuk IIH. ${ }^{2}$

Tahun 1893 Heinrich Quincke telah melaporkan catatan kasus dari hipertensi intrakranial yang tidak diketahui penyebabnya dan disebutkan sebagai meningitis serosa. Selanjutnya pada tahun 1904 Nonne menyebutkan sebagai pseudo tumor cerebri dan menguraikan keluhan yang dihubungkan dengan tumor intrakranial tapi dengan remisi yang tidak biasa. Tahun 1955 Foley menyebutkan kondisi ini sebagai benign intracranial hypertension. Dalam pandangan adanya konsekuensi yang serius berupa kehilangan penglihatan, nama benign intracranial hypertension diubah menjadi idiopathic intracranial hypertension. ${ }^{1-3}$ Penamaan IIH telah berubah dalam beberapa tahun, pertama kali disebut sebagai meningitis serosa, pseudotumor cerebri dan benign intracranial hypertension. Penamaan benign intracranial hypertension dianggap tidak tepat karena kondisi yang secara nyata mempengaruhi morbiditas dari sakit kepala kronis, bersama-sama dengan kehilangan penglihatan yang berat dan menetap pada $25 \%$ kasus. ${ }^{4}$ Rasio IIH antara perempuan dan lakilaki adalah 8:1. Insidensi IIH pada wanita yang masih dapat mempunyai anak adalah 0,9 per 100 ribu, yang meningkat menjadi 19,3 per 100 ribu pada wanita dengan obesitas. Prevalensi obesitas pada kehamilan meningkat dari 9-10\% pada awal 1990 -an menjadi $16-19 \%$ pada tahun 2000. Dengan meningkatnya prevalensi obesitas, kejadian IIH dalam kehamilan juga meningkat. ${ }^{1}$

Insidensi IIH adalah 0,9/100 ribu orang dan 3,5/100 ribu pada wanita dengan usia 15-44 tahun. Ada peningkatan insidensi seiring dengan meningkatnya obesitas. Pada wanita obes dengan berat badan $20 \%$ atau lebih dari berat badan ideal dengan usia 20 sampai 44 tahun, kejadian IIH adalah 19 per 100 ribu. Lebih dari $90 \%$ pasien IIH adalah obes dan lebih dari $90 \%$ wanita dalam masa subur. Walaupun keluhan dan gejala bisa rekuren pada $10 \%$ kasus, peningkatan tekanan intrakranial yang tanpa keluhan dapat menetap bertahun-tahun. Umur rerata saat terdiagnosis adalah 30 tahun. $^{2}$ Penelitian keadaan yang dihubungkan dengan IIH kebanyakan penelitian tanpa kelompok kontrol dan retrospektif. Hal ini membawa kearah simpulan yang salah disebabkan para peneliti mencoba mengimplikasi IIH menggunakan hubungan palsu dan untunguntungan dengan kondisi medikal dan pengobatan yang umum. ${ }^{2}$ Keluhan peningkatan tekanan intrakranial adalah sakit kepala, tinitus (pulsatile tinnitus), kehilangan sebagian penglihatan selintas, dan kehilangan pandangan. Gejalanya adalah diplopia yang disebabkan paresis saraf kranial ke-6 dan papil edema yang dihubungkan dengan hilangnya fungsi visual sensoris. Morbiditas yang besar dari IIH adalah kehilangan penglihatan. $^{2}$

\section{Patofisiologi Hipertensi Intrakranial}

Isi tengkorak terdiri dari jaringan otak $(86 \%)$, darah (4\%) dan cairan serebrospinal (cerebrospinal fluid/CSF) $10 \%$. Cairan serebrospinal dibentuk dengan kecepatan konstan, $80 \%$ atau lebih dibuat di pleksus koroideus, sisanya dibuat di parenkim otak. Fungsi cairan serebrospinal adalah untuk 
proteksi, sokongan, dan regulasi kimia otak. Produksi cairan serebrospinal kira-kira 0,35$0,4 \mathrm{ml} / \mathrm{menit}$ atau $30 \mathrm{ml} / \mathrm{jam}$ atau $500-600 \mathrm{ml} /$ hari. Absorpsinya bergantung pada perbedaan tekanan cairan serebrospinal dan vena. Absorpsi tersebut terjadi melalui villi khorialis. Beberapa obat anestesi mempengaruhi produksi dan absorpsi cairan serebrospinal. Volume dan tekanan cairan serebrospinal berbeda pada anak dan dewasa. ${ }^{5}$

Karena ruangan tersebut dikelilingi tulang maka peningkatan salah satu volume tersebut akan meningkatkan tekanan intrakranial. Sedikit peningkatan volume intrakranial akan dikompensasi dengan memindahkan CSF ke ruangan subarachnoid spinal dan penekanan volume darah vena, tetapi kompensasi ini sangat terbatas dan bila terlewati, setiap penambahan volume intrakranial akan meningkatkan tekanan intrakranial. ${ }^{5}$ Peningkatan tekanan intrakranial akan menurunkan tekanan perfusi otak dan menimbulkan iskemia serebral, juga akan menyebabkan herniasi uncal dan serebelar. Makin tinggi tekanan intrakranial, prognosis makin jelek. ${ }^{5}$ Tekanan intrakranial normal $5-15 \mathrm{mmHg}$. Tekanan ini tidak selalu konstan bergantung pada pulsasi arteri, respirasi, dan batuk. Peningkatan volume salah satu komponen (otak, darah atau cairan serebrospinal) akan dikompensasi dengan penurunan volume komponen yang lainnya. ${ }^{5}$

\section{Doktrin Monro-Kellie}

Volume intrakranial selalu konstan. Bila volume bertambah, misalnya karena ada hematom, maka untuk mengurangi volume, cairan serebrospinal

Tabel 1.3 Tekanan dan Volume CSF pada Manusia

\begin{tabular}{lc}
\hline & Rentang \\
\hline Tekanan CSF (mmH & $3,0-7,5$ \\
Anak-anak & $4,5-13,5$ \\
Dewasa & \\
Volume CSF (mL) & $40-60$ \\
Infant & $60-100$ \\
Anak kecil & $80-120$ \\
Anak yg lebih tua & $100-160$ \\
Dewasa & \\
\hline
\end{tabular}

Dikutip dari: Cottrell and Young’s, 2010 dan darah akan berkurang, dengan keluar dari ruangan intrakranial sehingga tekanan intrakranial akan tetap normal. Bila batas kompensasi dilewati, tekanan intrakranial akan meningkat (Gambar 1). ${ }^{5}$ Pada gambar 1, terlihat bahwa tekanan intrakranial tetap dalam batas normal walaupun volume bertambah (tanda $1 \mathrm{ke}$ 2), akan tetapi, apabila batas kompensasi dilalui (volume intrakranial terus bertambah), maka tekanan intrakranial akan meningkat dengan cepat (tanda 3 dan 4). Terapi harus dimulai bila tekanan intracranial $>20 \mathrm{mmHg}{ }^{5}$

Bila tekanan intrakranial meningkat dengan cepat, terjadi perubahan sistemik seperti hipertensi, hipotensi, takikardia, bradikardia, perubahan irama jantung, perubahan elektrokardiografi (EKG), gangguan elektrolit, hipoksia, dan neurogenic pulmonary edema (NPE). Cushing menuliskan adanya Trias Cushing pada pasien dengan kenaikkan tekanan intrakranial. Trias itu terdiri atas hipertensi, bradikardia dan melambatnya respirasi. Peningkatan tekanan darah ini merupakan mekanisme untuk mempertahankan aliran darah otak yang terjadi akibat peningkatan kadar adrenalin, nor-adrenalin, dopamin dalam sirkulasi. Bradikardi tidak selalu terjadi pada setiap pasien. Bradikardi dapat juga terjadi selintas, yang paling sering terjadi yaitu takikardia dan atau aritmia ventrikel. ${ }^{5}$ Pada keadaan tekanan intrakranial yang meningkat bisa terjadi spasme arteri serebral, yang bisa menimbulkan serebral iskemia dan serebral infark. Pada cedera kepala berat bisa terjadi laktik asidosis cairan serebrospinal, yang juga akan meningkatkan tekanan intrakranial. ${ }^{5}$

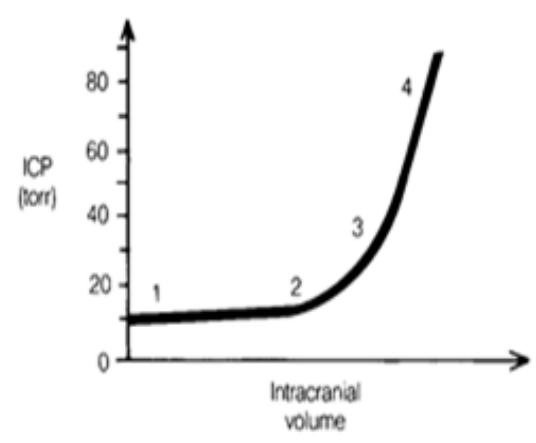

Gambar 1. Hubungan Peningkatan Volume Intrakranial dengan Hipertensi Intrakranial 


\section{Patogenesis IIH}

Patogenesis IIH belum jelas, telah diperkirakan disebabkan oleh gangguan dinamika cairan serebrospinalis. Tidak ada bukti yang jelas apakah hal ini adalah akibat dari peningkatan produksi cairan cerebrospinal (Cerebrospinal Fluid/CSF) pada pleksus choroideus atau hambatan drainase CSF pada jaringan granulasi arachnoid. ${ }^{1}$ Keluhan umum adalah sakit kepala dan gangguan penglihatan selintas. Sakit kepala dapat terjadi setiap hari dan khas sakit kepala retrobulber yang berdenyut-denyut yang bertambah buruk dengan pergerakan bola mata. Keadaan ini dihubungkan dengan mual, muntah dan photopobia. Kehilangan pandangan dapat berakhir dalam beberapa detik dan bisa parsial atau komplit. Keluhan penglihatan lain adalah pandangan kabur, kehilangan pandangan dan pandangan dobel. Kondisi ini dapat memperburuk migrain yang telah ada sebelumnya. Pasien dengan IIH juga dapat datang ke spesialis THT karena tinnitus, vertigo, ottorhoea dan rhinorhoea spontan.

Gejala IIH yang sering terjadi adalah papil edema (pembengkakkan diskus optikus akibat peningkatan tekanan intrakranial), defek lapang pandangan dengan pembesaran blind spot, penurunan ketajaman pandangan, pengurangan penglihatan warna dan kelumpuhan saraf ke-6. Kelumpuhan saraf ke- 6 terjadi akibat regangan saraf ini dengan angka Kejadian $>10 \%$ pasien IIH. Tidak korelasi langsung antara keluhan visual dan beratnya papil edema. ${ }^{1}$ Setiap hipotesis dari patogenesis IIH harus menerangkan observasi pasien berikut dengan kelainan ${ }^{2}$ : kejadian terbanyak pada wanita obes selama masa subur, menurunnya konduktans outflow CSF, ukuran ventrikel normal, tidak ada hidrosefalus, tidak ada bukti histologik dari edema serebral.

Telah dilaporkan adanya perubahan-perubahan pada hemodinamika serebral, yang meningkatkan volume darah otak dan menurunkan aliran darah otak. Akan tetapi, yang lain menemukan tidak ada perubahan yang signifikan pada faktor-faktor ini. Hipotesis yang paling populer adalah bahwa IIH adalah suatu sindroma akibat pengurangan absorpsi CSF. Pengurangan konduktans outflow CSF mungkin disebabkan disfungsi mekanisme absorpsi dari granulasi arachnoid atau kemungkinan melalui limpatik ekstrakranial. Mekanisme limpatik merupakan suatu rute drainase alternatif sepanjang nerve roots saraf ekstrakranial dan spinal ke limpatik ekstrakranial, yang dipublikasikan oleh Miles Johnston dkk, mungkin merupakan faktor penting dalam mekanisme IIH. ${ }^{2}$

Patogenesis IIH belum diketahui. Gangguan dinamika CSF adalah hal yang mendasarinya walaupun ada banyak spekulasi yang tidak meyakinkan pada literatur sebagai hubungan antara peningkatan produksi CSF pada pleksus khorideus atau hambatan drainase CSF pada jaringan granulasi arachnoid. ${ }^{4}$ Keluhan IIH adalah sakit kepala (94\%), transient visual obscuration (68\%), pulse synchronous tinnitus (58\%), photopsia $(54 \%)$, dan nyeri retrobulbair $(44 \%)$. Diplopia (38\%) dan kehilangan penglihatan (30\%) jarang menyertai IIH. ${ }^{2}$

\section{Diagnostik IIH}

Keluhan paling sering adalah sakit kepala (pada lebih dari $90 \%$ pasien) dan gangguan penglihatan (sampai $70 \%$ pasien), termasuk kehilangan pandangan sementara (transient visual obscuration), kehilangan lapangan pandangan, dan hilangnya ketajaman penglihatan. Banyak pasien mengalami tinnitus pulsatif. Keluhan lain adalah adanya sakit leher dan punggung, edema ekstremitas, diplopia (umumnya dari palsi abdusen unilateral atau bilateral, gejala peningkatan tekanan intrakranial), facial palsi, ataksia, dan parestesia. ${ }^{6}$

Gambaran klinisnya menunjukkan adanya sakit kepala, hilangnya pandangan akibat papil edema. Hal ini disebabkan karena peningkatan tekanan cairan serebrospinalis dengan gambaran CSF yang normal. Terapi umumnya dengan analgesik, kortikosteroids, inhibitor karbonik anhidrase dan diuretik (asetazolamide); bila pengendalian adekuat tidak tercapai maka dilakukan punksi lumbal untuk mengeluarkan cairan serebrospinal. Kejadian IIH sekitar 19,3 per 100 ribu wanita 


\section{Tabel 1. Modified Dandy Criteria}

- Gejala dan keluhan peningkatan tekanan intrakranial: sakit kepala, mual, muntah, kehilangan pandangan selintas, papil edema.

- Tidak ada gejala neurologik yang terlokalisi, kecuali paresis unilateral atau bilateral N VI

- Peningkatan tekanan cairan serebrospinalis, tapi tidak ada abnormalitas sitologik atau kimia.

- Harus ditunjukkan ventrikel simetris normal atau kecil dengan ventriculografi atau CT-scan.

Dikutip dari: Thirumalaikumar ${ }^{1}$

dalam masa reproduksi.Tidak indikasi untuk dilakukan aborsi. Hipertensi intrakranial yang tidak bisa dikendalikan memerlukan pengakhiran kehamilan dengan jalan yang paling cepat, pasien diinduksi atau dilakukan seksio sesarea. ${ }^{7}$ Diagnosa IIH pertama kali diperkenalkan oleh Dandy pada tahun 1937. Pada tabel dibawah ini ada kriteria diagnostik yang dibuat oleh Smith pada tahun 1985.

Tekanan CSF lumbal harus lebih besar dari $250 \mathrm{mmH} 2 \mathrm{O}$ yang diukur pada posisi lateral decubitus untuk mendiagnosa IIH. Neuroimaging penting untuk mengeklusi penyebab lain seperti hidrosefalus, lesi massa atau struktur. Satu laporan dalam kriteria diagnostik IIH mendukung bahwa CT-scan adekuat untuk mengeklusi hidrosefalus dan lesi massa. Akan tetapi, penyebab lain dari hipertensi intrakranial seperti trombosis sinus venosus tidak dapat terdeteksi, sehingga diperlukan magnetic resonance imaging. Satu penelitian retrospektif telah mengevaluasi penggunaan magnetic resonance venography pada wanita dengan IIH dan menyimpulkan bahwa magnetic resonance venography berguna pada atypical $\mathrm{IIH} .{ }^{1}$ Penemuan ophtalmik pada peningkatan tekanan intrakranial adalah papil edema.

Peningkatan tekanan CSF ditranmisikan melalui kanal optikus kedalam selubung saraf optikus intraorbital, yang menyebabkan papil edema (pembengkakkan serabut saraf pada saraf kepala), yang dapat asimetris. Papil edema dinilai dengan funduskopi atau teknik imaging discus. Kehilangan penglihatan berat yang memperberat IIH antara $10-20 \% .{ }^{1}$ Sindroma dari peningkatan

\section{Tabel 2. Kriteria Diagnosis untuk IIH}

- Keluhan, bila ada, berupa keluhan peningkatan tekanan intrakranial

- Gejala menunjukkan peningkatan tekanan intrakranial atau papil eema

- Peningkatan tekanan CSF pada posisi lateral decubitus $\left(>25 \mathrm{cmH}_{2} \mathrm{O}\right.$, dan hanya dengan sangat hati-hati pada tekanan yang lebih rendah)

- Komposisi CSF normal

- Pemeriksaan imaging untuk mengeksklusi hidrosefalus, lesi massa atau struktur dan eksklusi universal dari trmbosis sinus venosus (dianjurkan pemeriksaan magnetic resonanse atau computed tomogram venography).

- Tidak ada penyebab kenaikkan tekanan intrakranial sekunder yang didapatkan (anemia, obstructive sleep apnoe (OSA), Guillain-Barre Syndrome, atau efek obat misalnya antibiotik, NSAIDs, vitamin A, lithium, cimetidin).

Dikutip dari: Sinclair ${ }^{4}$

\section{Tabel 3. Modified Dandy Criteria}

1 Gejala dan/atau keluhan peningkatan tekanan intrakranial

2 Terdokumentasi peningkatan tekanan intrakranial $\left(>250 \mathrm{mmH}_{2} \mathrm{O}\right)$

3 Komposisi cairan serebrospinal normal

4 Harus ditunjukkan ventrikel simetris normal atau kecil dengan ventriculografi atau CT-scan.

5 Tidak ada bukti ada hidrosefalus, lesi massa, struktur atau vaskular pada pemeriksaan imaging

6 Tidak ada gejala neurologik terlokalisasi kecuali paresis N VI unilateral atau bilateral.

Dikutip dari: Badve $\mathrm{M}^{9}$

tekanan intrakranial tanpa hidrosefalus atau lesi massa dan dengan komposisi CSF normal, sebelumnya disebut sebagai pseudotumor serebri, adalah suatu diagnosis eksklusi yang sekarang disebut sebagai idiopathic intracranial hypertension (IIH). Kriteria diagnostik dari kelainan ini belum di update sejak kriteria Modifikasi Dundy dipakai pada tahun $1985 .{ }^{8}$

Diagnosis pseudotumor cerebri dapat dilakukan dengan kriteria modifikasi Dandy yaitu:1) keluhan dan gejala dari peningkatan tekanan intrakranial, 2) pemeriksaan neuroimaging normal, 3) tekanan 
CSF $250 \mathrm{~mm} \mathrm{H}_{2} \mathrm{O}$ atau lebih besar pada posisi lateral decubitus dalam keadaan pasien rileks, 4) kandungan CSF normal, dan 5) penyebab lain disingkirkan. ${ }^{6}$ Kriteria diagnosis IIH diawali pada tahun 1937 oleh Dandy dan walaupun baru-baru ini mendapat revisi, klarifikasi selanjutnya memerlukan kepentingan universal untuk menyingkirkan trombosis sinus venosus. Sebagai tambahan, batas peningkatan tekanan CSF harus ditentukan. Diagnosis ditegakkan dengan menggunakan modifikasi kriteria Dandy yang memerlukan peningkatan tekanan intrakranial $>250 \mathrm{mmH}_{2} \mathrm{O}$ dan menghilangkan keadaan patologik dengan pemeriksaan CSF dan radiologik seperti terlihat pada tabel dibawah ini. ${ }^{9}$

\section{Efek IIH pada Kehamilan}

Satu review kasus pada tahun 1972 mengomentari bahwa pengakhiran kehamilan harus dipertimbangkan bila gangguan penglihatan memburuk atau ada eksaserbasi IIH pada kehamilan sebelumnya. Hal ini telah menjadi perdebatan dengan modalitas terapi yang baru. Pengakhiran kehamilan tidak menjadi jaminan. Tidak ada peningkatan kejadian komplikasi obstetrik pada wanita dengan IIH. ${ }^{1}$

Tidak cukup bukti tentang mode yang aman untuk melahirkan bayi wanita dengan IIH. Satu serial kasus IIH pada wanita hamil telah melaporkan lebih dari 50\% melahirkan per vaginam. Peningkatan tekanan intrakranial yang terjadi selama persalinan adalah selintas dan tidak berbahaya untuk ibu dan bayi. Seksio sesarea tidak diperlukan secara rutin dan cara melahirkan bayi bergantung pada faktor obstetri saja. Suatu penelitian dengan menggunakan rancangan kasus kontrol menemukan tidak ada peningkatan komplikasi obstetrik pada IIH.

Kehilangan penglihatan terjadi dalam jumlah yang sama antara pasien IIH yang hamil dan yang tidak hamil. Mereka menyimpulkan bahwa terapi pasien IIH pada kehamilan sama dengan pada wanita yang tidak hamil, kecuali restriksi kalori harus diperhatikan. Penggunaan acetazolamide pada trimester pertama kehamilan merupakan hal yang kompleks. Disebabkan kerena kemungkinan efek teratogenik pada hewan dan satu kasus teratoma sacrococcygeal pada manusia, dasar penundaan penggunaan asetazolamid tidak kuat. $^{2,10}$

\section{Efek Kehamilan pada IIH}

Satu penelitian controlled study oleh Digre dkk telah menggambarkan bahwa kehamilan bukan merupakan faktor penyebab. Preeksisting IIH cenderung memburuk pada saat kehamilan, kemungkinan karena faktor penambahan berat badan. Outcome penglihatan pada wanita hamil sama dengan wanita yang tidak hamil. Kehamilan selanjutnya tidak berimplikasi sebagai faktor risiko untuk rekuren $\mathrm{IIH} .{ }^{1}$

Sakit kepala (headache) akibat IIH pada kehamilan harus dibedakan dengan penyebab lain. The International Classification of Headache Disorder membagi sakit kepala kedalam 3 kategori. Keluhan sakit kepala pada wanita hamil harus dipertimbangkan secara serius dan pendekatan sistematik adalah sangat penting.

\section{Tiga Kategori Headache}

- Headache Primer: migren atau tension headache, merupakan penyebab headache paling umum pada wanita hamil.

- Headache Sekunder: sekunder terhadap trauma, kelainan vaskular, IIH, infeksi, masalah pskiatrik

- Neuralgia kranial, central dan nyeri fasial primer, dan headache yang lain

Dikutip dari: Thirumalaikumar

Anamnesa yang detil tentang lokasi dan beratnya sakit kepala akan menolong mengidentifikasi penyebabnya. Keluhan gangguan penglihatan, muntah dan leher kaku menunjukkan adanya penyebab neurologik yang nyata.

Riwayat kelainan psikiatrik yang lalu dan oabatobatan (kafein, opioid, kanabis dan kokain) menunjukkan headache sekunder. Komplikasi yangmengancamjiwasepertieklampsia,trombosis vena serebral dan meningitis harus dieksklusi. Pemeriksaan mata, telinga, hidung, tenggorokan, 
Anamnesis: tempat, frekuensi, beratnya sakit kepala

Hubungan keluhan dengan gangguan penglihatan, muntah

Riwayat sakit kepala yang lalu

Riwayat obat yang dimakan

Riwayat kelainan psikiatrik

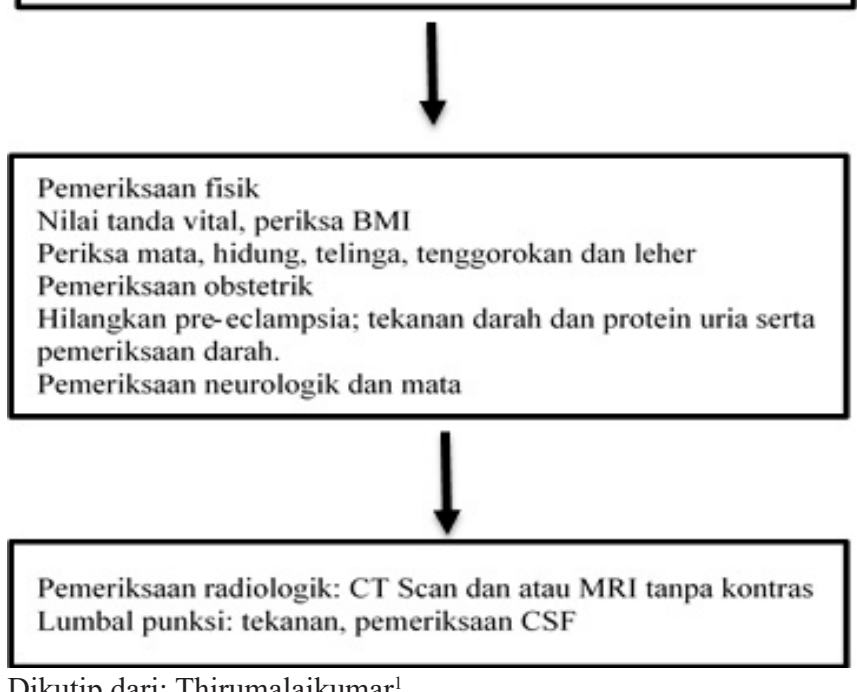

dan leher penting untuk mengeluarkan penyebab headache sekunder. Pemeriksaan imaging perlu untuk mengeluarkan tumor intrakranial dam kejadian thrombosis. Gambar dibawah ini menyimpulkan proses penilaian bila wanita hamil mengalami sakit kepala. ${ }^{1}$

\section{Peranan Obesitas dalam IIH}

Yang menarik pada IIH adalah lebih dari 93\% pasien adalah obesitas. Pada populasi obesitas kejadian IIH meningkat diatas 19 per 100 ribu, dibandingkan dengan 2,2 per 100 ribu pada populasi umum.

Prevalensi IIH meningkat dalam hubungan dengan epidemik global dari obesitas (lebih dari $24 \%$ orang dewasa di Inggris adalah obes) berperan pada morbiditas wanita muda yang obes. ${ }^{1,4}$ Hubungan antara obesitas dan IIH belum sepenuhnya dapat diterangkan dan spekulasi sehubungan dengan peranan dari distribusi lemak dan OSA masih belum dibuktikan kebenarannya. Sejumlah laporan kasus telah menghubungkan IIH dengan Cushing disease suatu kondisi adanya obesitas dengan peningkatan kortisol sirkulasi. ${ }^{1,4}$

\section{Terapi IIH}

Terapi IIH pada wanita hamil sama dengan terapi IIH pada wanita yang tidak hamil. Penanganan harusmultidisilin danmeliputineurologist, spesiali kandungan, anestetist, dan spesialis mata. Tujuan terapi adalah untuk memelihara penglihatan dan memperbaiki keluhan. Terapi medikal yang umum adalah analgetik, kortikosteroid, carbonic anhydrase inhibitor, dan diuretik; bila pengendalian adekuat tersebut tidak tercapai maka lakukan pengambilan CSF dari lumbal punksi. Diuretik perlu untuk mengurangi produksi CSF dan diet perlu untuk menurunkan berat badan. Opsi pembedahan termasuk melakukan lumbal punksi, dan fenestrasi selubung saraf optik. Bila hipertensi intrakranial tidak dapat dikontrol, lakukan pengakhiran kehamilan melalui rute yang paling cepat apakah dilakukan induksi persalinan atau seksio sesarea.,10,12 Terapi medikal dapat dilakukan dengan penurunan berat badan, lumbal punksi, pemberian kortikosteroid, acetazolamid. Terapi surgikal dapat dilakukan dengan dekompresi subtemporal atau suboccipital, fenestrasi selubung saraf optik, prosedur shunting CSF, operasi oklusi gaster, stenting sinus venosus. ${ }^{2,13,14}$ 


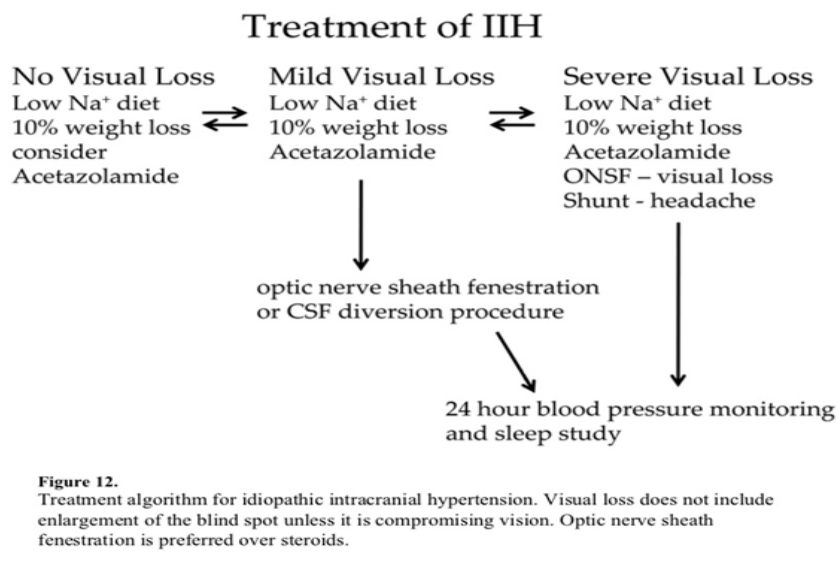

Dikutip dari: Wall $\mathrm{M}^{2}$

\section{Implikasi Anestesi pada IIH}

Pasien yang terdiagnosa kehamilan dengan IIH dapat melahirkan dengan cara intratechal labor analgesia (ILA) atau seksio sesarea. Tekanan CSF meningkat sebagai respon terhadap kontraksi miometrium dan berhubungan dengan peningkatan tekanan vena sentral, isi sekuncup, curah jantung dan tekanan darah arteri. ${ }^{15-16}$

Anetesi regional baik epidural atau spinal telah dinyatakan berhasil untuk seksio sesarea. Anestesi spinal lebih dianjurkan karena lebih aman untuk wanita dengan IIH. Hal ini disebabkan karena punksi lumbal untuk drainase CSF digunakan sebagai modalitas terapi IIH. Teknik epidural anestesia harus dipertimbangkan terlebih dahulu. Epidural anestesi membawa kemungkinan untuk peningkatan tekanan intrakranial dengan volume obat yang besar dalam ruangan epidural. ${ }^{15-16}$ Perhatian harus ditujukan pada wanita dengan shunt lumbo-peritoneal yang memerlukan anestesi regional, karena ada kemungkinan terjadi kerusakan shunt. Imaging sebelumnya diperlukan disebabkan adanya risiko belitan dari shunt.

Anestesi umum untuk seksio sesarea pada wanita hamil dengan IIH dianjurkan apabila dengan terapi drainse CSF tidak berfungsi dengan baik. Anestesi umum membawa risiko peningkatan tekanan intrakranial akibat rapid sequence induction. ${ }^{1}$ saat melakukan anestesi umum yang merupakan pertimbangan adalah pada saat induksi dan laringoskopi intubasi memiliki resiko terjadinya tekanan intrakranial, kemungkian kesulitan intubasi akibat terjadinya obesitas. Saat melakukan ventilasi hindari hiperventilasi dapat mengakibatkan menurunnya aliran darak kepada janin yang akan berakibat hipoksia dan asidosis. Anestesi umum, spinal anestesi, epidural anestesi telah dilakukan pada pasien $\mathrm{IIH} .{ }^{1,15-16}$

\section{Simpulan}

Hipertensi intrakranial idiopatik ditandai dengan peningkatan tekanan CSF dengan penyebab yang belum diketahui, merupakan penyakit yang predominan pada wanita dalam masa subur. Walaupun penyebab IIH masih tidak jelas, tapi sering terjadi hilangnya fungsi penglihatan dan berkembang kearah kebutaan bila tidak di terapi. Diagnosa mengikuti modifikasi kriteria Dandy dan penyebab lain dari hipertensi intrakranial yang ditemukan. Pengelolaan pasien IIH harus termasuk perimetri serial dan grading diskus optikus atau fotografi. Kemudian, dapat dipilih terapi yang lebih baik dan dilakukan pencegahan kehilangan penglihatan.

Walaupun tidak ada bukti berdasarkan data untuk panduan terapi, masih dilakukan penelitian RCT untuk terapi diet dan medikal. Hipertensi intrakranial idiopatik yang tidak bisa dikontrol memerlukan pengakhiran kehamilan melalui rute yang paling cepat, dengan induksi partus spontan atau seksio sesarea. Prognosis IIH 
dalam kehamilan adalah baik untuk ibu dan bayi. Anestesi dapat dilakukan dengan spinal anestesia, epidural anestesia, combined spinal epidural atau anestesi umum.

\section{Daftar Pustaka}

1. Thirumalaikumar L, Ramalingam K, Heafield T. Idiopathic intracranial hypertension in pregnancy. The Obstetrician \& Gynecologist 2014;16:93-97.

2. Wall M. Idiopathic intracranial hypertension. Neurol Clin 2010;28(3):593-617.

3. Aly EE, Lawther BK. Anesthetic management of uncontrolled idiopathic intracranial hypertension during labour and delivery using an intrathecal catheter. Anesthesia 2007; 2(2):178-81.

4. Sinclair A. Idiopathic intracranial hypertension: recent concept and development. ACNR 2010; 10(3): 10-14.

5. Bisri DY, Bisri T. Pengelolaan Perioperatif Cedera Otak Traumatik, edisi-4. Bandung: Fakultas Kedokteran Universitas Padjadjaran; 2018.

6. Evans RW, Friedman DI. The management of pseudotumor cerebri during pregnancy. Headache 2000;40:495-97.

7. Manuel DG, Julia CR, Jose GL. Clinical management of delivery in pregnant women with idiopathic intracranial hypertension. ARC Journal of Gynecology and Obsterics 2017;2(1):4-6.

8. Friedman DI, Jacobson DM. Diagnostic criteria for idiopathic intracranial hypertension. Neurology 2002;59:1492.
9. Badve M, McConnell MJ, Shah T, Ondecko-Ligda KM, Poutous GW, Vallejo MC. Idiopathic intracranial hypertension in pregnancy treated with serial lumbar punctures. International journal of Clinical Medicine 2011;2: 9-12.

10. Bagga R, Jain V, Gupta KR, Gopalan S, Malhotra S, Das CP. Choice of therapy and mode of delivery in idiopathic intracranial hypertension during pregnancy. MedscapeGeneral Medicine 2005; 7 (4):42.

11. Butala BP, Shah VR. Anaesthetic management of a case of idiopathic intracranial hypertension. Indian J Anaesth 2013; 57(4):401-3.

12. 12. Tang RA. Management of idiopathic intracranial hypertension in pregnancy. MedGenMed 2005;7(4):40.

13. Huna-Baron R, Kupersmith MJ. Idiopathic intracranial hypertension in pregnancy. $\mathrm{J}$ Neurol 2002; 249:1078-81.

14. Falardeau J, Lobb BM, Golden S, Maxfield SD, Tanne E. The use of acetazolamide during pregnancy in intracranial hypertension patients. J Neuro-Ophthalmol 2013;33:9-12.

15. Worrel J, Lane S. Impact of pseudotumor cerebri (idiopathic intracranial hypertension) in pregnancy: a case report. AANA 2007;75(3): 199-204.

16. Karmaniolou I, Petropoulos G, Theodoraki $\mathrm{K}$. Management of idiopathic intracranial hypertension in parturients: anesthetic considerations. J Can Anesth (2011) 58:650 67. 